\title{
Correction: An integrated approach for aquifer characterization and groundwater productivity evaluation in the Lake Haramaya watershed, Ethiopia
}

\author{
Haile A. Shishaye ${ }^{1} \cdot$ Douglas R. Tait $^{1} \cdot$ Kevin M. Befus ${ }^{2} \cdot$ Damien T. Maher $^{1}$
}

Published online: 30 April 2019

(C) Springer-Verlag GmbH Germany, part of Springer Nature 2019

Correction: Hydrogeology Journal

https://doi.org/10.1007/s10040-019-01956-7

Figure 6 was incorrectly labelled in the original article. The correct Figure 6 is presented here.

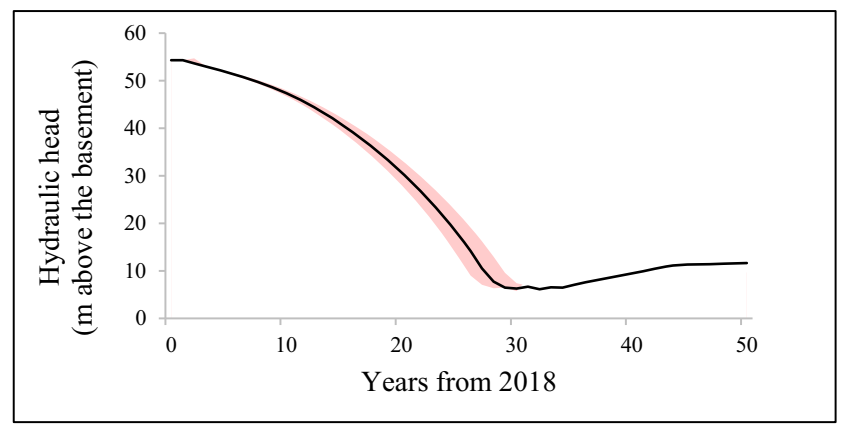

Fig. 6 Predicted hydraulic heads of the groundwater in the Lake Haramaya watershed. Predictions were made using the current extraction rate $\left(\sim 30,120 \mathrm{~m}^{3} /\right.$ day $\pm 5 \%$ /annum $)$ and average $K$ value \pm standard error (SE)

The online version of the original article can be found at https://doi.org/10. 1007/s10040-019-01956-7

Haile A. Shishaye

haile.4.hiwot@gmail.com

1 Southern Cross Geoscience, Southern Cross University,

Lismore, New South Wales, Australia

2 Civil and Architectural Engineering, University of Wyoming,

Laramie, WY, USA 